\title{
EFEK PEMBERIAN EKSTRAK KAYU MANIS (CINNAMOMUM BURMANNII) TERHADAP GAMBARAN HISTOPATOLOGI LAMBUNG TIKUS WISTAR YANG DIBERI ASPIRIN
}

\author{
${ }^{1}$ Janet Walangitan \\ ${ }^{2}$ Lily Loho \\ ${ }^{2}$ Meilany Durry \\ ${ }^{1}$ Kandidat Skripsi Fakultas Kedokteran Universitas Sam Ratulangi Manado \\ ${ }^{2}$ Bagian Patologi Anatomi Fakultas Kedokteran, Universitas Sam Ratulangi Manado
}

\begin{abstract}
Cinnamon (Cinnamomum burmannii) is a traditional herbal plants which are often found in our daily life and has many benefits especially in health. This study were designed to know the effect of cinnamon on gastric mucosa given aspirin. This was an experimental research and used Wistar rats as the subject research. The Wistar rats were randomly divided into 6 mice of control group and 9 mice of treatment group. Group A (K-) given pellets, group $\mathrm{B}(\mathrm{K}+)$ given pellets and aspirin $150 \mathrm{mg} / \mathrm{kgBB}$ for 7 days, group C given pellets, aspirin 150 $\mathrm{mg} / \mathrm{kgBB}$ and cinnamon extract $3 \mathrm{mg}$ for 3 days, group D given pellets, aspirin $150 \mathrm{mg} / \mathrm{kgBB}$ for 7 days and given cinnamon extract $3 \mathrm{mg}$ for 3 days, group E given pellets, aspirin 150 $\mathrm{mg} / \mathrm{kgBB}$ for 7 days and given pellets only (without treatment) for 3 days. The results showed that aspirin cause gastric mucosa damage in group B $(\mathrm{K}+)$ compared with kelompok A (K-). Group C and D showed less inflammatory cells compared with group B $(\mathrm{K}+)$. Group E showed more inflammatory cells compared with group D. The study suggested that cinnamon extract has protective and therapeutic effects on gastric mucosa of Wistar rats.
\end{abstract}

Keywords: cinnamon, gaster, aspirin.

\begin{abstract}
Abstrak: Kayu manis (Cinnamomum burmannii) merupakan tanaman herbal tradisional yang banyak dijumpai dalam kehidupan sehari- hari dan memiliki banyak manfaat termasuk dalam bidang kesehatan. Penelitian ini bertujuan untuk mengetahui apakah ada efek pemberian kayu manis terhadap mukosa lambung yang diberi aspirin. Desain Penelitian yang digunakan adalah metode eksperimental dan subjek penelitian menggunakan tikus Wistar, yang terbagi atas 6 ekor kontrol dan 9 ekor perlakuan. Kelompok A (K-) diberikan pelet selama 7 hari, kelompok B (K+) diberikan pelet dan aspirin 150mg/kgBB selama 7 hari, kelompok C diberikan pelet, aspirin 150 $\mathrm{mg} / \mathrm{kgBB}$, ekstrak kayu manis $3 \mathrm{mg}$ secara bersama- sama selama 7 hari, kelompok D diberikan pelet dan Aspirin $150 \mathrm{mg} / \mathrm{kgBB}$ selama 7 hari dilanjutkan dengan pemberian ekstrak kayu manis 3 mg selama 3 hari, kelompok E diberikan pelet dan Aspirin 150 mg/kgBB selama 7 hari dilanjutkan dengan pemberian pelet saja (tanpa perlakuan) selama 3 hari. Hasilnya menunjukkan aspirin menimbulkan kerusakan mukosa lambung pada kelompok $\mathrm{B}(\mathrm{K}+)$ dibandingkan dengan kelompok A (K-). Kelompok C dan D menunjukkan sel-sel radang yang lebih sedikit dari kelompok B(kontrol +). Kelompok E menunjukkan sel- sel radang yang lebih banyak dibandingkan dengan kelompok D. Kesimpulan dari penelitian ini adalah kayu manis mempunyai efek protektif dan terapeutik terhadap mukosa lambung tikus Wistar.
\end{abstract}

Kata kunci: kayu manis, lambung, aspirin. 
Kayu manis merupakan tanaman yang telah digunakan sejak dulu sebagai bumbu masak serta ramuan obat herbal tradisional. Tercatat 54 jenis tanaman kayu manis (Cinnamomum sp.) yang tersebar di seluruh dunia dan 12 jenis diantaranya terdapat di Indonesia. ${ }^{1}$ Cinnamomum burmannii merupakan salah satu jenis kayu manis yang berasal dari Indonesia. ${ }^{2}$ Kulit, daun dan minyak kayu manis diolah dan dimanfaatkan sebagai penyedap makanan dan minuman, dan banyak digunakan dalam bidang kosmetik. Selain itu, kayu manis juga bermanfaat untuk kesehatan antara lain memiliki efek untuk melindungi lambung. ${ }^{3}$

Lambung merupakan organ pada saluran pencernaan berbentuk seperti kantong dengan fungsi utama sebagai tempat penampungan makanan dan mengatur makanan masuk duodenum dalam ukuran sedikit dan teratur. ${ }^{4}$ Lambung terdiri atas beberapa lapisan, yaitu lapisan mukosa, sub mukosa, muskularis, subserosa dan serosa. ${ }^{5}$

Gastritis merupakan keadaan inflamasi mukosa dan submukosa lambung yang termasuk dalam gangguan kesehatan yang paling sering dijumpai di klinik. ${ }^{6}$ Penyebabnya antara lain adalah infeksi bakteri Helicobacter pylori dan beberapa bahan makanan tertentu yang bersifat iritatif, seperti alkohol dan aspirin dapat secara khusus merusak sawar mukosa pelindung lambung. ${ }^{7}$

Asam asetil salisilat yang lebih dikenal sebagai asetosal atau aspirin merupakan obat analgesik antipiretik dan anti inflamasi non steroid (OAINS) yang luas digunakan dan digolongkan dalam obat bebas. ${ }^{8}$

Berdasarkan uraian diatas, penulis tertarik untuk melakukan penelitian mengenai efek pemberian kayu manis terhadap gambaran histopatologi lambung tikus wistar yang diberikan aspirin.

\section{METODE PENELITIAN}

Anatomi Fakultas Kedokteran Universitas Sam Ratulangi Manado dan dilaksanakan pada bulan September 2013 sampai Februari 2014.

\section{Subjek penelitian}

Subjek penelitian yang digunakan adalah 15 ekor tikus Wistar, yaitu 6 ekor tikus kontrol dan 9 ekor tikus perlakuan. Kelompok A (kontrol negatif) diberikan pelet selama 7 hari, kelompok B (kontrol positif) diberikan pelet dan aspirin 150mg/kgBB selama 7 hari, kelompok C (perlakuan 1) diberikan pelet, aspirin 150 $\mathrm{mg} / \mathrm{kgBB}$, ekstrak kayu manis $3 \mathrm{mg}$ secara bersama- sama selama 7 hari, kelompok D (perlakuan 2) diberikan pelet dan Aspirin $150 \mathrm{mg} / \mathrm{kgBB}$ selama 7 hari dilanjutkan dengan pemberian ekstrak kayu manis $3 \mathrm{mg}$ selama 3 hari, kelompok E (perlakuan 3) diberikan pelet dan Aspirin $150 \mathrm{mg} / \mathrm{kgBB}$ selama 7 hari dilanjutkan dengan pemberian pelet saja (tanpa perlakuan) selama 3 hari.

\section{HASIL PENELITIAN}

\section{Gambaran makroskopik}

Data dan gambaran makroskopik lambung dapat dilihat pada Tabel 1 dan Gambar 1a-e.

Tabel 1.

\begin{tabular}{lllllll}
\hline Wistar & Warna & Konsistensi & $\begin{array}{l}\text { Panjang } \\
(\mathbf{c m})\end{array}$ & $\begin{array}{l}\text { Lebar } \\
(\mathbf{c m})\end{array}$ & $\begin{array}{l}\text { Tebal } \\
(\mathbf{c m})\end{array}$ & $\begin{array}{l}\text { Berat } \\
(\mathbf{g r})\end{array}$ \\
\hline A & Kemerahan & Kenyal & 2,8 & 1,2 & 1,3 & 2,56 \\
B & Pucat & Kenyal & 3,1 & 2,1 & 2,0 & 2,3 \\
& Pucat & Kenyal & 3,3 & 2,5 & 1,8 & 1,85 \\
C & Pucat & Kenyal & 2,5 & 1,9 & 1,5 & 1,43 \\
& Kemerahan & Kenyal & 2,3 & 1,5 & 1,6 & 2,23 \\
& Kemerahan & Kenyal & 2,7 & 1,6 & 1,4 & 1,55 \\
\multirow{2}{*}{ D } & Kemerahan & Kenyal & 2,5 & 1,2 & 1,5 & 1,64 \\
& Kemerahan & Kenyal & 2,7 & 1,0 & 1,3 & 1,55 \\
\multirow{2}{*}{ E } & Kemerahan & Kenyal & 2,9 & 2,2 & 1,6 & 2,40 \\
& Kemerahan & Kenyal & 2,8 & 2,0 & 1,5 & 1,77 \\
\hline
\end{tabular}

Pemeriksaan secara makroskopik dimulai pada saat otopsi melalui pengamatan warna, konsistensi, ukuran, dan berat lambung tikus. Berdasarkan pengamatan lambung secara makroskopik pemberian aspirin saja menyebabkan warna lambung menjadi lebih pucat dibandingkan dengan kelompok lainnya. Konsistensi lambung secara umum sama pada kelompok kontrol 
dan perlakuan. Ukuran dan berat lambung tikus bervariasi antara satu kelompok dengan kelompok lain.

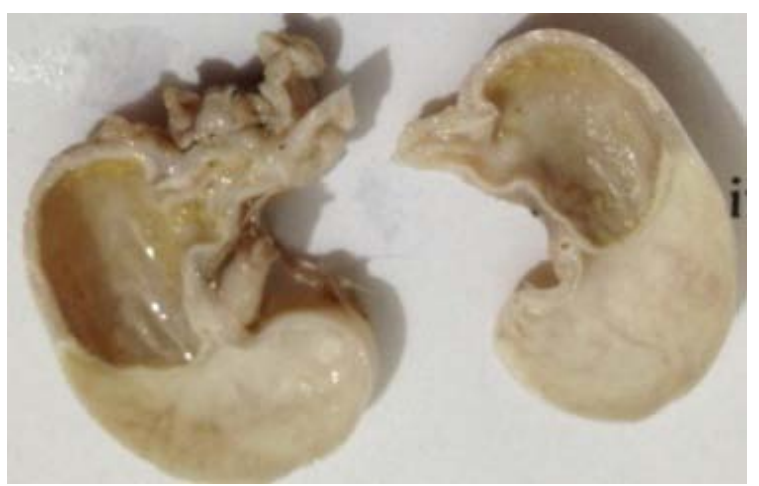

Gambar 1a. Gambaran makroskopik lambung tikus wistar kelompok A (kontrol negatif), Wistar hanya diberikan pelet standart sampai hari ke-7.

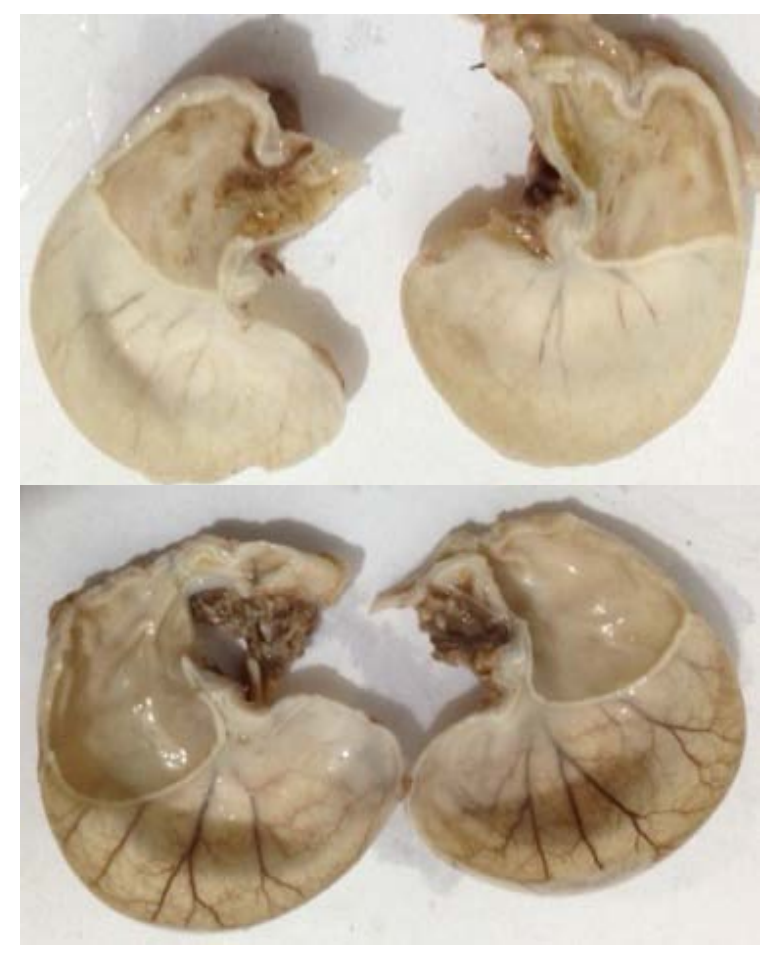

Gambar 1b. Gambaran makroskopik lambung tikus wistar kelompok B (kontrol positif), Wistar diberikan aspirin $30 \mathrm{mg}$ selama-7 hari.

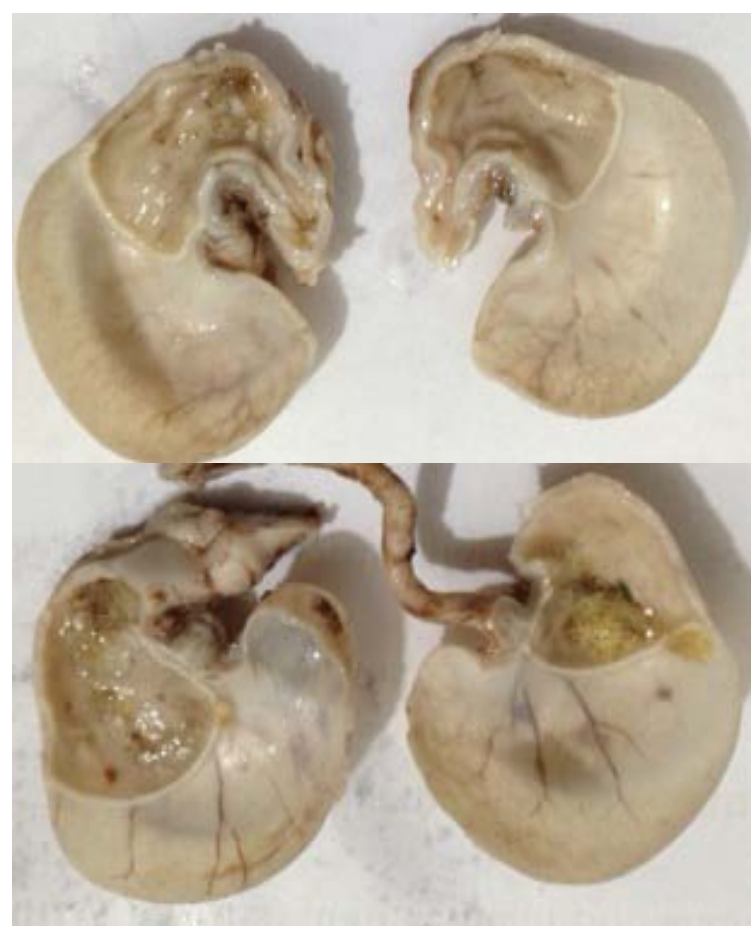

Gambar 1c. Gambaran makroskopik lambung tikus wistar kelompok C (perlakuan 1), Wistar diberikan aspirin $30 \mathrm{mg}$ bersama- sama dengan ekstrak kayu manis dengan dosis 3 mg selama 7 hari.

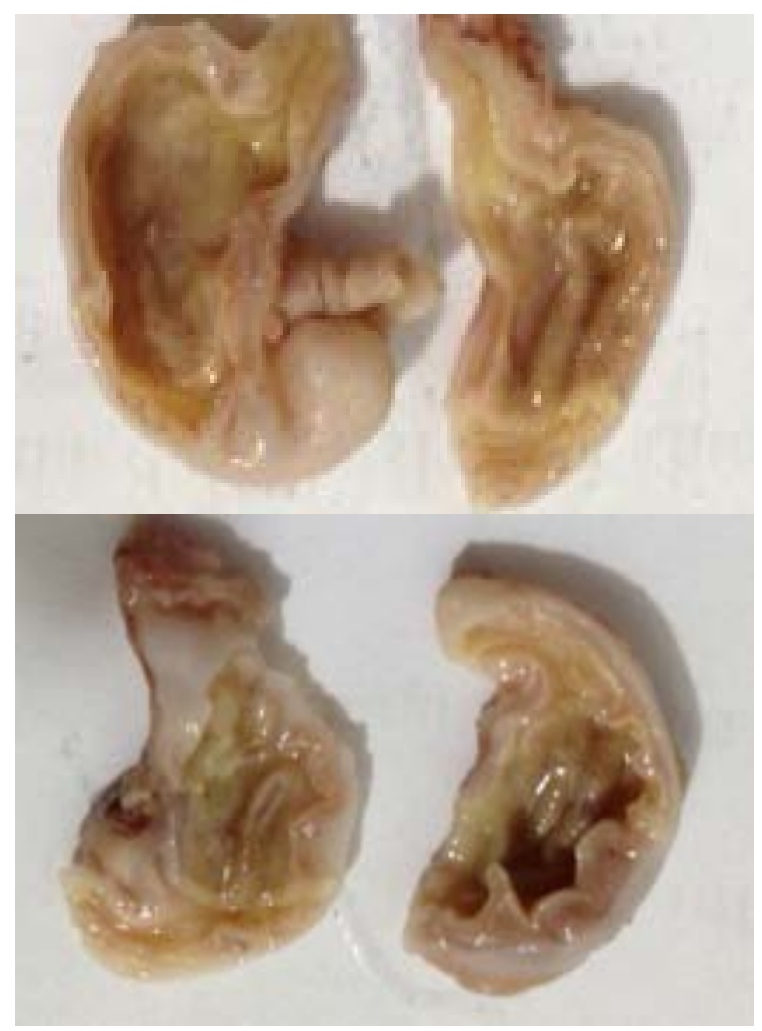

Gambar 1d. Gambaran makroskopik lambung tikus wistar kelompok D (perlakuan 2), Wistar diberikan aspirin $30 \mathrm{mg}$ selama 7 hari dilanjutkan dengan pemberian ekstrak kayu manis dengan dosis $3 \mathrm{mg}$ selama 3 hari. 


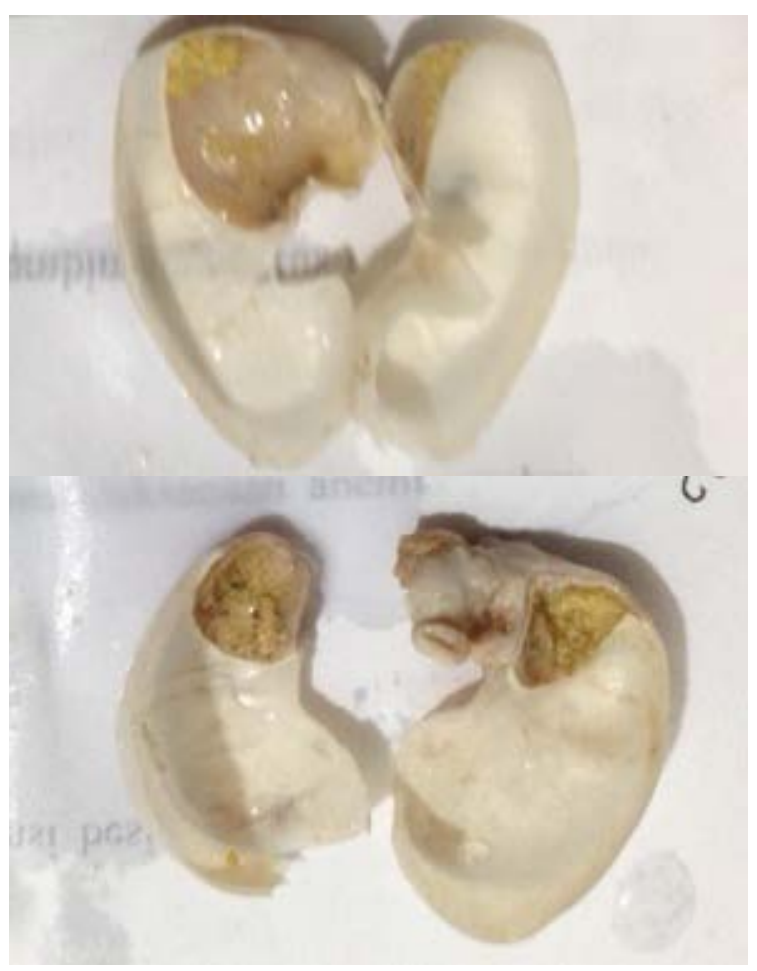

Gambar 1e. Gambaran makroskopik lambung tikus wistar kelompok E (perlakuan 3), Wistar diberikan aspirin $30 \mathrm{mg}$ selama 7 hari dan dilanjutkan dengan pemberian pellet saja (tidak diberikan perlakuan) selama 3 hari.

\section{Gambaran mikroskopik}

\section{Tikus Wistar kelompok A}

Gambaran mikroskopik lambung menunjukkan dinding lambung yang normal. Kelenjar-kelenjar mukosa, sel parietal, sel chief dan sel neuroendokrin juga tampak normal. Tampak juga lapisan mukosa, submukosa, muskularis dan serosa dalam keadaan normal dengan sel radang yang sangat sedikit.

\section{Tikus wistar kelompok B}

Gambaran mikroskopis lambung menunjukkan adanya sel-sel radang yang banyak sampai di submukosa, epitel permukaan mukosa yang menipis di bagian tertentu dan terjadi pelebaran kapiler.

\section{Tikus Wistar kelompok $C$}

Gambaran mikroskopis lambung menunjukkan adanya sel-sel radang yang lebih sedikit dibandingkan pada kelompok B yang hanya diberikan aspirin selama 7 hari. Ini menunjukkan bahwa pemberian kayu manis terbukti dapat mengurangi sel-sel radang pada gambaran histopatologi lambung tikus Wistar.

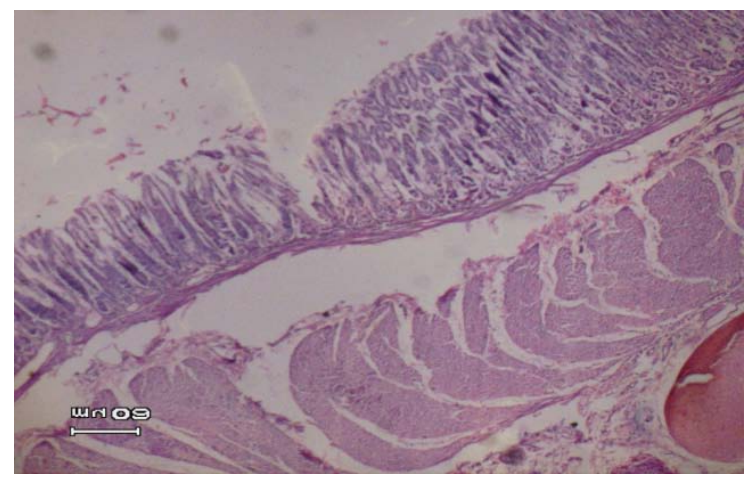

Gambar 2. Gambaran lambung tikus wistar kelompok A (kontrol negatif) yang diberikan pelet selama 7 hari, terlihat gambaran mikroskopik lambung yang normal.

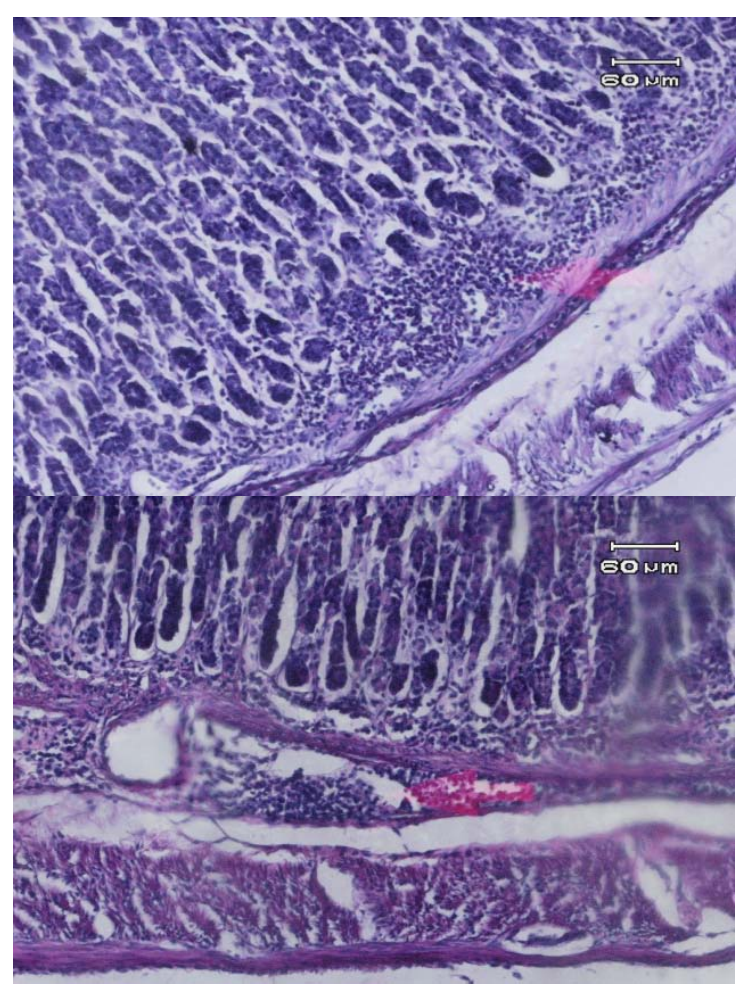

Gambar 3. Gambaran mikroskopik lambung tikus Wistar kelompok B (kontrol positif) yang diberikan aspirin $30 \mathrm{mg}$ selama 7 hari.

Gambaran mikroskopis lambung menunjukkan adanya sel-sel radang yang lebih sedikit dibandingkan kelompok B. Ini menunjukan bahwa kayu manis terbukti dapat 
mengurangi sel-sel radang pada mukosa lambung tikus Wistar yang diberikan aspirin. Jika dibandingkan dengan kelompok C, terdapat lebih banyak sel-sel radang pada kelompok D. Ini menunjukkan bahwa efek protektif ekstrak kayu manis lebih baik dibandingkan dengan efek terapeutik pada mukosa lambung tikus Wistar yang diberikan aspirin.

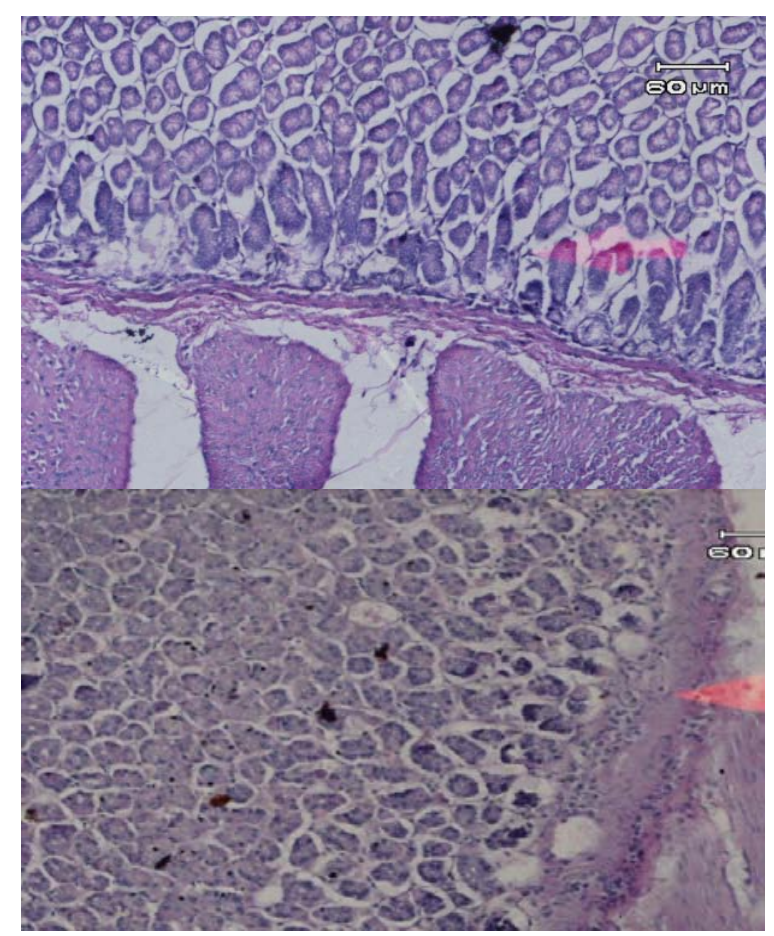

Gambar 4. Gambaran mikroskopik lambung tikus Wistar kelompok C yang diberikan aspirin 30 mg bersama-sama dengan ekstrak kayu manis dengan dosis $3 \mathrm{mg}$ selama 7 hari.

\section{Tikus Wistar kelompok D}

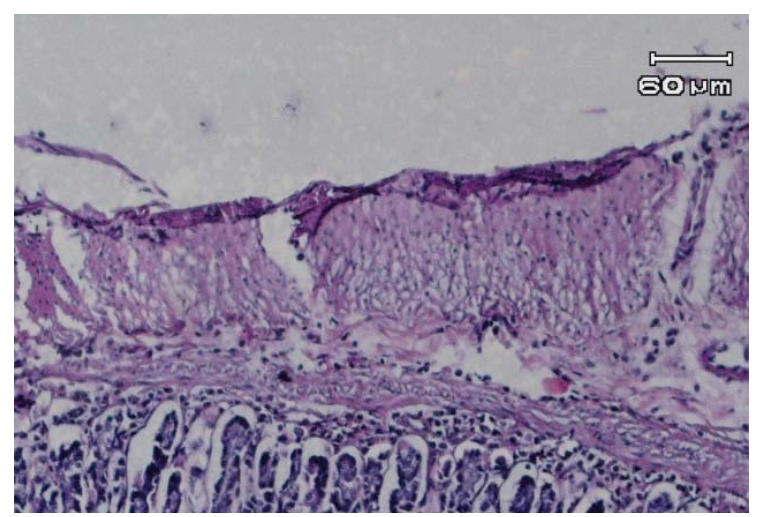

Gambar 5. Gambaran mikroskopik lambung tikus Wistar kelompok D yang diberikan aspirin $30 \mathrm{mg}$ selama 7 hari dilanjutkan dengan pemberian ekstrak kayu manis dengan dosis 3 mg selama 3 hari.

\section{Tikus Wistar kelompok E}

Gambaran mikroskopis lambung menunjukkan adanya sel-sel radang yang lebih sedikit dibandingkan pada kelompok B yang hanya diberikan aspirin saja. Tetapi jika dibandingkan dengan kelompok $\mathrm{D}$, terlihat sel-sel radang yang lebih banyak pada kelompok E. Ini menunjukkan penyembuhan dengan kayu manis lebih efektif dibandingkan hanya dengan penyembuhan fisiologis saja.

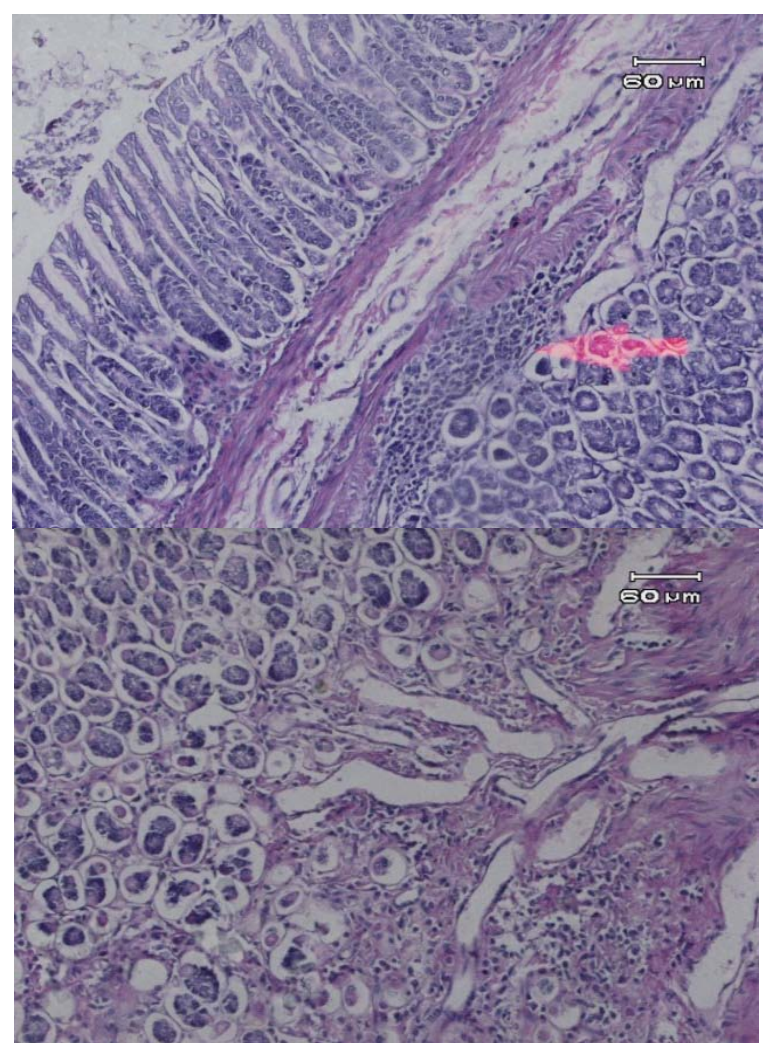

Gambar 6. Gambaran mikroskopik lambung tikus Wistar kelompok E yang diberikan aspirin $30 \mathrm{mg}$ selama 7 hari, dan tidak diberikan perlakuan selama 3 hari (hanya diberikan pellet saja).

\section{BAHASAN}

Dari penelitian ini didapatkan hasil pada kelompok A, tikus Wistar yang hanya diberikan pelet saja menunjukkan gambaran makroskopik lambung yang relatif normal, baik warna, ukuran, maupun konsistensi. Begitu juga dengan gambaran 
mikroskopisnya yang menunjukkan gambaran struktur lapisan lambung yang normal.

Pada kelompok B, tikus Wistar dengan perlakuan pemberian aspirin $30 \mathrm{mg}$ selama 7 hari gambaran makroskopik lambung tampak pucat. Pada gambaran mikroskopik terdapat banyak sel-sel radang pada lapisan mukosa sampai submukosa, epitel permukaan mukosa menipis dan terjadi pelebaran kapiler. Hal ini disebabkan aspirin menghambat sintesis prostaglandin melalui penghambatan enzim siklo-oksigenase-1 sehingga menghambat sintesis PGE2 yang bertugas mengatur sekresi asam lambung dan perlindungan mukosa sehingga aliran darah mukosa terganggu dan hilangnya lapisan mukus yang melindungi mukosa lambung. ${ }^{8}$

Pemberian ekstrak kayu manis bersama-sama dengan aspirin selama 7 hari pada kelompok C, secara makroskopik lambung tampak normal yaitu kemerahan seperti pada kelompok kontrol. Gambaran mikroskopis menunjukkan adanya sel radang netrofil tetapi lebih sedikit dibandingkan kelompok yang hanya diberikan aspirin saja. Hal ini menunjukan efek proteksi ekstrak kayu manis terhadap lambung. Kayu manis bekerja sebagai proton pump inhibitor dengan cara menghambat aksi pompa $\mathrm{H}+/ \mathrm{K}+\mathrm{ATPase}$, sehingga ion $\mathrm{H}+$ tidak bisa keluar, dan akibatnya $\mathrm{HCl}$ tidak terbentuk menyebabkan sekresi asam lambung terhambat. Dalam kayu manis terdapat kandungan minyak atsiri yang bermanfaat sebagai anti inflamasi sehingga dapat mengurangi kerusakan lambung yang disebabkan oleh aspirin. ${ }^{9}$

Pada kelompok D dengan perlakuan pemberian aspirin $150 \mathrm{mg} / \mathrm{kgBB}$ selama 7 hari dilanjutkan dengan pemberian ekstrak kayu manis selama 3 hari, secara makroskopik menunjukkan warna, konsistensi dan ukuran lambung normal. Gambaran mikroskopiknya masih tampak adanya sel-sel radang di mukosa lambung dengan jumlah yang sedikit. Kayu manis mengandung minyak atsiri yang bermanfaat sebagai antioksidan sehingga minyak atsiri yang terdapat dalam kayu manis mampu menetralisir radikal- radikal bebas yang dihasilkan selama proses radang. Hasilnya, proses radang yang terjadi dapat berkurang. Secara mikroskopik, didapatkan sel radang yang lebih sedikit pada kelompok D dibandingkan kelompok $\mathrm{E}$ yang diberikan aspirin $150 \mathrm{mg} / \mathrm{kgBB} /$ hari selama 7 hari dan tidak diberikan perlakuan selama 3 hari. Berkurangnya sel- sel radang pada kelompok ini lebih lambat dibandingkan kelompok D yang proses penyembuhannya dibantu dengan pemberian ekstrak kayu manis. Ini menunjukan efek terapeutik dari ekstrak kayu manis lebih efektif untuk menyembuhkan peradangan lambung dibandingkan dengan penyembuhan fisiologis. ${ }^{9}$

\section{SIMPULAN}

Berdasarkan hasil penelitian yang didapat disimpulkan bahwa ekstrak kayu manis mempunyai efek protektif dan terapetik terhadap mukosa lambung tikus Wistar yang diberikan aspirin.

\section{DAFTAR PUSTAKA}

1. Daswir. Profil tanaman kayu manis di indonesia. Accessed at : 2007. Available from : http://balittro.litbang.deptan.go.id

2. Aprianto. Ekstraksi oleresin dari kayu manis berbantu ultrasonik dengan menggunakan pelarut alkohol. Accessed at: Okt 2011. Available from http://eprints.undip.ac.id/36560/2/Tesis_pen elitian_ekstraksi_kayu_manis_Aprianto.pdf.

3. Bambang I. Herbal indonesia. Edisi ke-1. Jakarta:PT Trubus Swadaya;2012

4. Loho L. Patologi saluran pencernaan. Edisi ke- 1. Manado ;2002.h.21

5. AJ Rama. Waspadai kanker lambung. Edisi ke-1. Jogjakarta: Buku Biru;2012.h.13-14

6. Anonim. Gastroenterologi. Dalam: Aru WS, Bambang S, Idrus A, Marcelus SK, Siti S, editor. Buku ajar ilmu penyakit dalam. Edisi ke-5. Jakarta: Interna Publishing; 2009.h.509

7. Guyton A, Hall J. Fisiologi gangguan gastrointestinal. Dalam: Luqman R, Huriawati H, Andita N, Nanda W, editor. Buku ajar fisiologi kedokteran. Edisi ke-11. Jakarta: EGC; 2008.h.861

8. Setiabudy R. Analgesik antipiretik analgesik anti-inflamasi nonsteroid dan obat gangguan sendi lainnya. Dalam: Sulistia 
GG, Rianto S, Nafrialdi, Elysabeth, editor. Farmakologi dan terapi. Edisi ke-5. Jakarta: Balai Penerbit FKUI; 2007.h.234

9. Raymond R T, Florensia N, Poppy FA. Hydrogen potassium adenosine triphosphatase activity inhibition and downregulation of its expression by bioactive fraction DLBS2411 from Cinnamomum burmannii in gastric parietal cells. International Journal of General Medicine. 2013. 